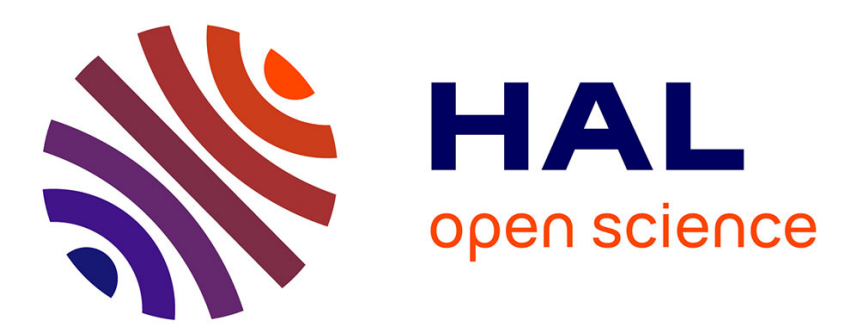

\title{
Maternal alcohol and coffee drinking, parental smoking and childhood leukaemia: a French population-based case-control study.
}

Florence Menegaux, Mahaut Ripert, Denis Hémon, Jacqueline Clavel

\section{- To cite this version:}

Florence Menegaux, Mahaut Ripert, Denis Hémon, Jacqueline Clavel. Maternal alcohol and coffee drinking, parental smoking and childhood leukaemia: a French population-based case-control study.. Paediatric and Perinatal Epidemiology, 2007, 21 (4), pp.293-9. 10.1111/j.1365-3016.2007.00824.x . inserm-00173807

\section{HAL Id: inserm-00173807 https://www.hal.inserm.fr/inserm-00173807}

Submitted on 1 Jul 2008

HAL is a multi-disciplinary open access archive for the deposit and dissemination of scientific research documents, whether they are published or not. The documents may come from teaching and research institutions in France or abroad, or from public or private research centers.
L'archive ouverte pluridisciplinaire HAL, est destinée au dépôt et à la diffusion de documents scientifiques de niveau recherche, publiés ou non, émanant des établissements d'enseignement et de recherche français ou étrangers, des laboratoires publics ou privés. 


\section{HAL author manuscript}

Maternal alcohol and coffee drinking, parental smoking and childhood

leukemia: a French population-based case-control study

Menegaux F, Ripert M, Hémon D, Clavel J.

INSERM, U754, IFR69, Université Paris-Sud 11, Villejuif, France.

\section{Running title}

Alcohol, coffee, smoking and childhood leukemia

\section{Key words}

Case-control study; childhood leukemia; alcohol; coffee; smoking

Corresponding author

Dr Florence Menegaux

INSERM U754

16, av. Paul Vaillant-Couturier

F-94807 VILLEJUIF Cedex

Tel: 33145595153

Fax: 33145595151 / 33145596020

Email:menegaux@vjf.inserm.fr 


\section{Summary}

The role of maternal alcohol and coffee drinking during pregnancy and that of parental smoking in the etiology of childhood leukemia were investigated.

A French, population-based, case-control study including 472 (407 acute lymphoblastic leukemia, ALL and 62 acute myeloblastic leukemia, AML) incident cases of childhood acute leukemia (AL) and 567 population controls frequency matched with cases on age, gender and region of residence was conducted. The case and control mothers filled in a comprehensive self-administered standardized questionnaire eliciting detailed data on maternal alcohol and coffee consumption during pregnancy and parental smoking before, during and after pregnancy.

Maternal alcohol consumption of more than 1 drink per day was related to ALL $(\mathrm{OR}=2.8[1.8,5.9])$. While maternal coffee consumption was not significantly related to $\mathrm{AL}(\mathrm{OR}=1.4[0.9,2.3])$, highest intake of coffee (more than 3 cups per day) during pregnancy was associated to $\mathrm{AL}$ in children whose mothers were non-smokers $(\mathrm{OR}=1.9[1.0,3.5])$. No association with parental smoking, either maternal or paternal, was observed in acute leukemia.

The present results suggest a possible role of the highest consumption of alcohol by the mother during pregnancy in the etiology of childhood acute leukemia. 
Acute leukemia $(A L)$ is the most common cancer in children aged less than 15 years, with an incidence of 43 cases per million and per year in France.$^{1}$ With the exception of exposure to x-rays, specific chemotherapy and some genetic syndromes, relatively little is known about the causes of childhood acute leukemia. Its young age distribution suggests that events or environmental exposures occurring in the pre- or perinatal periods or during pregnancy may affect its pathogenesis. Factors such as maternal alcohol and coffee drinking during pregnancy and parental smoking are relatively prevalent and may play a role in the etiology of childhood leukaemia, either directly or indirectly through their influence on other metabolites. The literature on maternal alcohol and coffee drinking during pregnancy is relatively scarce. An association between acute myeloid leukemia (AML) and maternal alcohol drinking during pregnancy was observed in all 4 studies on $A M L .^{2-5}$ The results for maternal alcohol and coffee drinking during pregnancy and acute lymphoid leukemia (ALL) are more inconsistent. Studies on maternal smoking before, during or after pregnancy do not appear to suggest an association with $\mathrm{AL}$. The results for paternal smoking are more inconsistent and call for further investigation. 


\section{METHODS}

A population-based case-control study was conducted in 14 regions of France between 1995 and 1998. The study design has been described in detail elsewhere. ${ }^{6}$ The cases were derived from the National Registry of Childhood Blood Malignancies (NRCL). In order for cases to be eligible, acute leukemia was to have been newly diagnosed in subjects aged less than 15 years and residing in metropolitan France at the time of diagnosis. The eligibility criteria for cases also included the physician's consent to the mother being contacted and the mother's ability to fill in a selfadministered questionnaire. During the period 1995-1998, the NRCL registered 786 cases of acute leukemia in the 14 regions, of whom 140 were not eligible: 25 were not known at the time of the study, 2 were known not to have parents, 3 had parents who were unable to fill out the questionnaire and 110 were too sick for their parents to be interviewed. Out of the 646 eligible cases, 472 (72\%) were included, consisting of 407 cases of ALL, 62 of AML and 3 of acute leukemia NOS

Controls were randomly selected from the overall population from a sample of 30,000 phone numbers representative of the French population with respect to region of residence and municipality population category. Recruitment was frequency matched on age, gender and region using quotas determined a priori on the basis of the expected distribution of cases. Out of the 805 eligible controls, 572 (71\%) completed the questionnaire. Five cases were excluded because they turned out to be adopted and finally 567 controls (70\%) were included.

The mothers completed a standardized self-administered questionnaire that was distributed by the physician for the cases and sent by mail to the controls. Data on parental socio-demographic characteristics and occupational history, pregnancy history, birth characteristics, the child's illnesses and familial history of cancer were 
collected. The data on smoking habits included the number of cigarettes smoked per day by the mother, 3 months before pregnancy, during pregnancy and from birth to diagnosis, and the number of cigarettes smoked per day by the father, 3 months before pregnancy and from birth to diagnosis. The data on maternal alcohol and coffee consumption during pregnancy included the number of alcoholic drinks per day of wine, beer or cider, in the one hand, and of spirits or liquor, on the other hand, and the number of cups of coffee per day (without any distinction between instant/ground or regular/decaffeinated).

The analyses were performed using the $\mathrm{SAS}^{\circledR}$ software package (version 9.1, Cary, North Carolina). Unconditional logistic regression models were used to estimate odds ratios $(\mathrm{OR})$ and $95 \%$ confidence intervals $(\mathrm{Cl})$. All analyses were adjusted for the stratification variables. Socio-demographic factors such as the mother's educational level, place of residence at diagnosis and other factors that had been previously been shown to be related to childhood leukemia in the present study were also included as potential confounders. ${ }^{6}$ 


\section{RESULTS}

There were no major differences between the cases and controls with respect to gender, age, region of residence at diagnosis, parental socio-professional category, parental educational level or population of the place of residence (Table 1).

An association between childhood leukemia and maternal alcohol consumption of more than 1 drink per day $(\mathrm{OR}=2.3[1.1,4.9])$ (Table 2) was observed. The relationship was restricted to consumption of wine, beer or cider, since very few mothers reported having drank spirits, and even none more than a glass per day. The results were similar for ALL. No AML case had a mother who drank more than 1 drink per day.

Maternal coffee consumption of more than 3 cups per day during pregnancy was slightly, although not significantly, associated to acute leukemia $(O R=1.4[0.9,2.3])$ (Table 3). The estimates were similar for ALL and AML.

No association between AL and parental smoking whether maternal or paternal was observed (Table 3). However, maternal smoking during pregnancy was associated to ALL $(O R=1.4[1.0,1.9])$. All results related to parental smoking and AML showed ORs lower than 1.0 but they were all based on very small numbers (less than 10 cases). Interestingly, the association with maternal coffee consumption of at least 3 cups/day during pregnancy was different for smokers $(0.9[0.3,2.4])$ and non-smokers $(1.9$ $[1.0,3.5])$. However, the interaction between maternal coffee drinking and maternal smoking during pregnancy was not significant.

The estimates for $\mathrm{AL}$ were unchanged when maternal alcohol, coffee drinking and parental smoking were included in the same model (Table 4). The observed association between ALL and maternal smoking during pregnancy did not remain 
significant after adjustment for maternal coffee and alcohol consumption during pregnancy $(\mathrm{OR}=1.3[0.9,1.9])$.

The results remained unchanged after adjustment for socio-demographic factors (parental socio-professional categories, parental educational levels, place of residence) and for factors that had previously been shown to be related to childhood leukemia in the present study, such as birth order, repeated early common infections, day-care attendance and familial history of cancer. ${ }^{6}$ 


\section{DISCUSSION}

The role of maternal alcohol and coffee drinking during pregnancy, and parental smoking in childhood acute leukemia was investigated in a French, populationbased, case-control study including 472 incident cases and 567 controls. An association with maternal alcohol consumption of more than 1 drink per day during pregnancy was observed. The highest consumption (more than 3 cups per day) of maternal coffee during pregnancy was related to $A L$ in children whose mothers were non-smokers. Finally, no association with parental smoking was observed.

The exhaustiveness of the NRCL was estimated to be $99 \%$, making selection in the case-identification process unlikely. ${ }^{1}$ The attending physician's consent was required for inclusion of each case. This may have tended to select cases in better medical condition and underestimate those whose health was more seriously compromised such as children with AML or infants aged less than 2 years. However, the distributions of parental smoking and maternal alcohol and coffee drinking during pregnancy were very similar for the surviving cases and those who died after inclusion in the study.

Twenty-seven percent of the cases did not answer the questionnaire. However, the age, gender and region distributions were similar for respondent and non-respondent cases.

The controls were randomly selected from the overall population. There was no difference between the cases and controls for the stratification variables (age, gender and region at the time of diagnosis) or for the socio-demographic characteristics 
(parental educational level, socio-professional category), indicating that the recruitment process for the control group was successful.

The control group in the study was compared with the overall population from two French population-based surveys conducted on representative samples of 5508 and 13459 deliveries in 1981 and 1995, respectively. ${ }^{7}$ The controls' mothers had smoking habits and alcohol consumptions, especially for consumptions of more than 2 drinks per day, which were similar to those of the mothers interviewed in the surveys.

Over- and under-declaration by the case and control mothers were minimized in the present study, due to the fact that the use of standardized questionnaires reduced potential differential misclassifications. The general feeling of guilt associated with smoking and alcohol drinking may be stronger in mothers of children with $A L$ than in mothers of healthy children. Such a bias seems unable to explain the absence of a relationship with smoking. Moreover, if the same guilt feeling had existed for alcohol drinking during pregnancy, it would have tended to underestimate the association. However, an association was clearly demonstrated. Conversely, non-differential misclassifications with respect to the number of cigarettes smoked or to the quantities of coffee or alcohol consumed during pregnancy are rather more likely. Besides, as expected, low birth weights were more frequent in children whose mother smoked during pregnancy. No particular birth outcome was associated with alcohol drinking, but the intake may be too low on average to produce an observable relationship.

Most of the literature concurs with respect to the absence of a relationship between parental smoking and childhood leukemia. ${ }^{2,4-5,8-14}$ Few studies have found maternal smoking to be significantly associated with the risk of ALL. ${ }^{15-16}$ Interestingly, two 
studies have reported an association with maternal smoking that was restricted to children presenting with the CYP1A1*1 mutant genotype. ${ }^{11,17}$ The role of paternal smoking during childhood has been much less investigated, but most of the studies did not observe an association. ${ }^{4-5,10,14}$

With regard to maternal alcohol consumption during pregnancy, the proportion of mothers consuming more than 1 drink per day was the same for the control group of this study and the population-based surveys. ${ }^{7}$ No association with ALL was reported by Van Steensel-Moll et al. 1985, Petridou et al. 1997, or Schuz et al. 1999..$^{8-9,12}$ Infante-Rivard et al. even observed an inverse association with ALL, but those authors also reported a positive association with maternal alcohol drinking during the second or third trimester of pregnancy for children with a null GSTM1 genotype or a CYP2E1*5 mutation. ${ }^{18}$ Although very few studies of $\mathrm{AML}$ are available, they all evidenced a positive association with alcohol consumption. ${ }^{2-5}$ The influence of maternal alcohol intake may differ according to the kind of alcohol. In France, wine and beer to a lesser extent are the most popular drinks, while in other countries spirits and liquor might be preferred. The observed OR of 1.9 associated with high maternal coffee drinking during pregnancy in non-smoking mothers may be observed by chance in subgroup analyses, but it may also reflect a direct or indirect effect of caffeine. Interestingly, it has been shown that, for a given caffeine intake, blood caffeine concentrations were lower in smokers than in non-smoking women. ${ }^{19}$ Moreover, Ross et al. have suggested that coffee may act as an inhibitor of DNA topoisomerase II and induce abnormalities of chromosome 11q23 that resemble those induced by epipodophyllotoxins. ${ }^{20}$ To the best of the authors' knowledge, only 4 studies have investigated the association between maternal coffee drinking and 
childhood leukemia. ${ }^{5,9,20-21}$ An association was reported in two of those studies with OR values close to $2.5 .^{5,20}$

In conclusion, the present results suggest a possible role of the highest consumption of maternal alcohol during pregnancy in the etiology of childhood acute leukemia. 


\section{AKNOWLEDGMENTS}

This work was supported by grants from Inserm, the Ministère de l'Environnement et de l'Aménagement du Territoire, the Fondation pour la Recherche Médicale, the Association pour la Recherche contre le Cancer, the Fondation de France and the Institut Electicité Santé.

We are grateful to Sabine Mélèze (Institut Démoscopie), who coordinated the random selection of the controls, to Martine Valdes and Dominique Ridondelli (Inserm U170) for technical assistance, and to Andrew Mullarky for his skillful revision of the manuscript. 


\section{REFERENCES}

1. Clavel J, Goubin A, Auclerc MF, Auvrignon A, Waterkeyn C, Patte C, et al. Incidence of childhood leukaemia and non-Hodgkin's lymphoma in France: National Registry of Childhood Leukaemia and Lymphoma, 1990-1999. European Journal of Cancer Prevention 2004; 13: 97-103.

2. Severson RK, Buckley JD, Woods WG, Benjamin D, Robison LL. Cigarette smoking and alcohol consumption by parents of children with acute myeloid leukemia: an analysis within morphological subgroups - a report from the Children's Cancer Group. Cancer Epidemiology, Biomarkers \& Prevention 1993; 2: 433-439.

3. Van Duijn CM, van Steensel-Moll HA, Coebergh JW, van Zanen GE. Risk factors for childhood acute non-lymphocytic leukemia: an association with maternal alcohol consumption during pregnancy? Cancer Epidemiology, Biomarkers \& Prevention 1994; 3: 457-460.

4. Shu XO, Ross JA, Pendergrass TW, Reaman GH, Lampkin B, Robison LL. Parental Alcohol Consumption, Cigarette Smoking, and Risk of Infant Leukemia: a Childrens Cancer Group Study. Journal of National Cancer Institute 1996; 88: 24-31.

5. Menegaux F, Steffen C, Bellec S, Baruchel A, Lescoeur B, Leverger G, et al. Maternal coffee and alcohol consumption during pregnancy, parental smoking and risk of childhood acute leukemia. Cancer Detection and Prevention 2005; 29: 487493. 
6. Jourdan-Da Silva N, Perel Y, Mechinaud F, Plouvier E, Gandemer V, Lutz P, et al. Infectious diseases in the first year of life, perinatal characteristics and childhood acute leukaemia. British Journal of Cancer 2004; 90: 139-145.

7. Blondel B, Norton J, du Mazaubrun C, Breart G. [Development of the main indicators of perinatal health in metropolitan France between 1995 and 1998. Results of the national perinatal survey]. Journal de gynécologie, obstétrique et biologie de la reproduction (Paris) 2001; 30: 552-564.

8. van Steensel-Moll HA, Valkenburg HA, Vandenbroucke JP, van Zanen GE. Are maternal fertility problems related to childhood leukaemia? International Journal of Epidemiology 1985; 14: 555-559.

9. Petridou E, Trichopoulos D, Kalapothaki V, Pourtsidis A, Kogevinas M, Kalmanti $M$, et al. The risk profile of childhood leukaemia in Greece: a nationwide case-control study. British Journal of Cancer 1997; 76: 1241-1247.

10. Brondum J, Shu XO, Steinbuch M, Severson RK, Potter JD, Robison LL. Parental cigarette smoking and the risk of acute leukemia in children. Cancer 1999; 85: 13801388.

11. Infante-Rivard C, Krajinovic M, Labuda D, Sinnett D. Parental smoking, CYP1A1 genetic polymorphisms and childhood leukemia (Quebec, Canada). Cancer Causes \& Control 2000; 11: 547-53 
12. Schuz J, Kaatsch P, Kaletsch U, Meinert R, Michaelis J. Association of childhood cancer with factors related to pregnancy and birth. International Journal of Epidemiology 1999; 28: 631-639.

13. Okcu MF, Goodman KJ, Carozza SE, Weiss NS, Burau KD, Bleyer WA, et al. Birth weight, ethnicity, and occurrence of cancer in children: a population-based, incident case-control study in the State of Texas, USA. Cancer Causes \& Control 2002; 13: 595-602.

14. Pang D, McNally R, Birch JM. Parental smoking and childhood cancer: results from the United Kingdom Childhood Cancer Study. British Journal of Cancer 2003; 88:373-381.

15. Stjernfeldt M, Berglund $\mathrm{K}$, Lindsten J, Ludvigsson J. Maternal smoking during pregnancy and risk of childhood cancer. Lancet 1986; 1: 1350-1352.

16. John EM, Savitz DA, Sandler DP. Prenatal exposure to parents' smoking and childhood cancer. American Journal of Epidemiology 1991; 133:123-132.

17. Clavel J, Bellec S, Rebouissou S, Menegaux F, Feunteun J, Bonaiti-Pellie C, et al. Childhood leukaemia, polymorphisms of metabolism enzyme genes, and interactions with maternal tobacco, coffee and alcohol consumption during pregnancy. European Journal of Cancer Prevention 2005; 14: 531-540. 
18. Infante-Rivard C, Krajinovic M, Labuda D, Sinnett D. Childhood acute lymphoblastic leukemia associated with parental alcohol consumption and polymorphisms of carcinogen-metabolizing genes. Epidemiology 2002; 13: 277-281.

19. Cook DG, Peacock JL, Feyerabend C, Carey IM, Jarvis MJ, Anderson HR, et al. Relation of caffeine intake and blood caffeine concentrations during pregnancy to fetal growth: prospective population based study. British Medical Journal 1996; 313: 1358-1362.

20. Ross JA. Maternal diet and infant leukemia: a role for DNA topoisomerase II inhibitors? International Journal of Cancer 1998; Supplement 11: 26-28.

21. Peters JM, Preston-Martin S, London SJ, Bowman JD, Buckley JD, Thomas DC. Processed meats and risk of childhood leukemia. Cancer Causes \& Control 1994; 5: 195-202. 


\begin{tabular}{|c|c|c|c|}
\hline & $\begin{array}{c}\text { Cases (\%) } \\
n=472\end{array}$ & $\begin{array}{c}\text { Controls (\%) } \\
n=567\end{array}$ & $p$ \\
\hline $\begin{array}{r}\text { Gender }^{*} \\
\text { Male }\end{array}$ & 260 & 326 (58) & ns \\
\hline $\begin{array}{l}\text { Age at diagnosis (year) } \\
\quad<2 \\
\quad 2-3 \\
4-5 \\
6-9 \\
\geq 10\end{array}$ & $\begin{array}{r}44 \\
115 \\
1124) \\
110(23) \\
113(24) \\
90\end{array}$ & $\begin{array}{rr}78 & (14) \\
148 & (26) \\
109 & (19) \\
130 & (23) \\
102 & (18)\end{array}$ & ns \\
\hline $\begin{array}{l}\text { Region of residence at diagnosis } \\
\text { Aquitaine } \\
\text { Bretagne } \\
\text { Centre } \\
\text { Franche-Comté / Alsace } \\
\text { Languedoc-Roussillon } \\
\text { Midi-Pyrénées } \\
\text { Haute / Basse Normandie } \\
\text { Pays de Loire } \\
\text { Picardie / Champagne Ardennes } \\
\text { Poitou-Charentes / Limousin }\end{array}$ & $\begin{array}{rr}59 & (13) \\
45 & (10) \\
51 & (11) \\
56 & (12) \\
31 & (7) \\
32 & (7) \\
58 & (12) \\
48 & (10) \\
53 & (11) \\
39 & (8)\end{array}$ & $\begin{array}{rr}42 & (7) \\
70 & (12) \\
62 & (11) \\
60 & (11) \\
48 & (8) \\
42 & (7) \\
55 & (10) \\
75 & (13) \\
69 & (12) \\
44 & (8)\end{array}$ & ns \\
\hline $\begin{array}{l}\text { Parental socio-professional category } \\
\text { Professional, technical workers, } \\
\text { administrators, managers } \\
\text { Clerical, sales and services workers } \\
\text { Factory and agricultural workers }\end{array}$ & $\begin{aligned} 196 & (42) \\
86 & (18) \\
186 & (40)\end{aligned}$ & $\begin{array}{ll}228 & (41) \\
134 & (24) \\
200 & (36)\end{array}$ & ns \\
\hline $\begin{array}{c}\text { Maternal education } \\
\leq \text { High school } \\
>\text { High school }\end{array}$ & $\begin{array}{ll}336 & (74) \\
120 & (26)\end{array}$ & $\begin{array}{ll}415 & (74) \\
144 & (26)\end{array}$ & is \\
\hline $\begin{array}{c}\text { Paternal education } \\
\leq \text { High school } \\
>\text { High school }\end{array}$ & $\begin{array}{ll}336 & (77) \\
102 & (23)\end{array}$ & $\begin{array}{ll}424 & (79) \\
113 & (21)\end{array}$ & ns \\
\hline $\begin{array}{l}\text { Place of residence at diagnosis (population) } \\
\quad<2,000 \\
2,000-9,999 \\
10,000-49,999 \\
50,000-19,999 \\
\geq 200,000\end{array}$ & $\begin{array}{rr}165 & (37) \\
75 & (17) \\
58 & (13) \\
64 & (14) \\
86 & (19)\end{array}$ & $\begin{array}{rr}223 & (39) \\
100 & (18) \\
62 & (11) \\
82 & (15) \\
98 & (17)\end{array}$ & ns \\
\hline
\end{tabular}

${ }^{*}$ Stratification variables

ns: $p>0.05$ 
Table 2: Maternal alcohol consumption and childhood leukemia

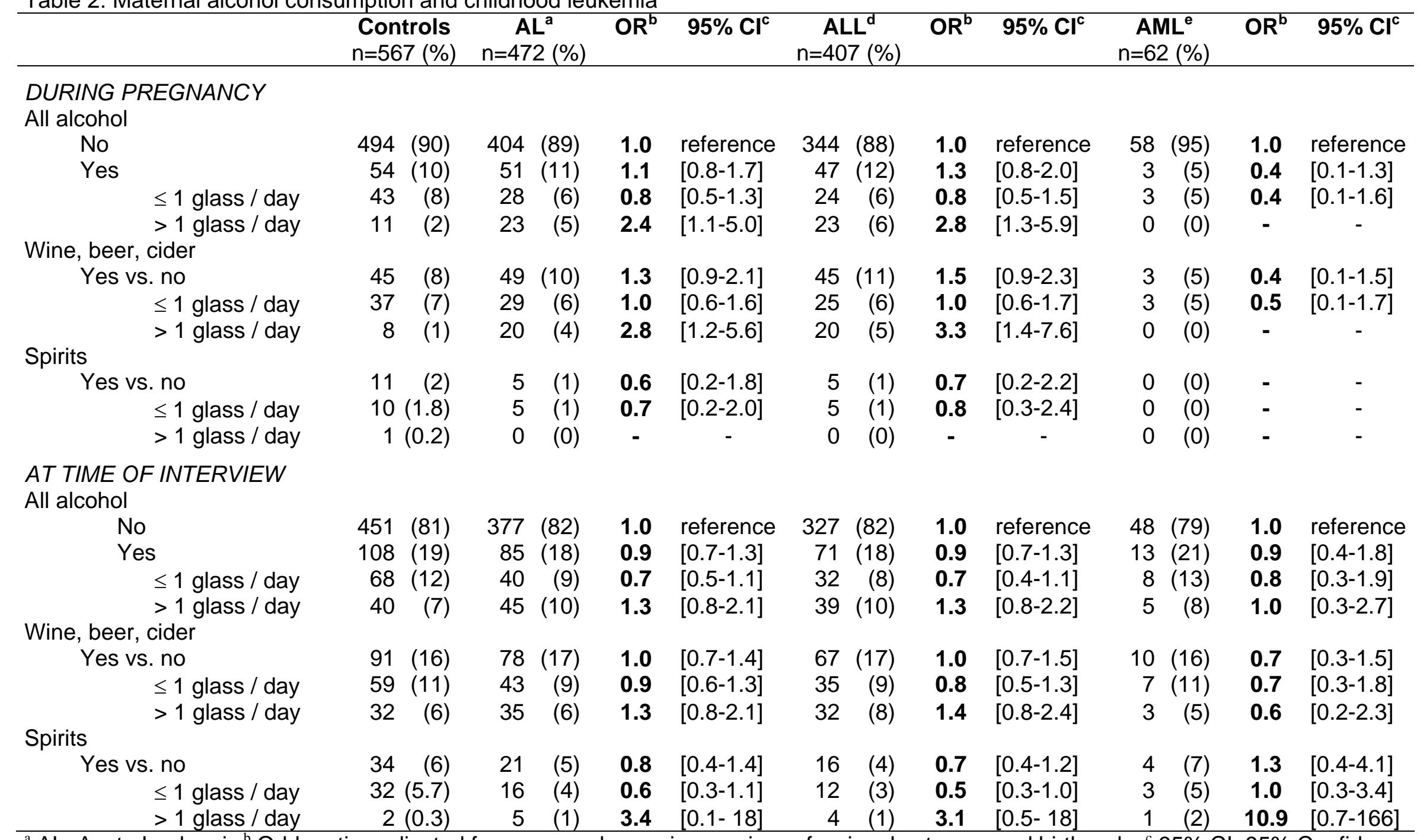

${ }^{\mathrm{a}} \mathrm{AL}$ : Acute Leukemia ${ }^{\mathrm{b}}$ Odds ratios adjusted for age, gender, region, socio-professional category and birth order $^{\mathrm{c}} 95 \% \mathrm{Cl}$ : $95 \%$ Confidence Interval ${ }^{\mathrm{d}}$ ALL: Acute Lymphoblastic Leukemia ${ }^{\mathrm{e}}$ AML: Acute Myeloblastic Leukemia 
Table 3: Maternal coffee consumption and childhood leukemia

\begin{tabular}{|c|c|c|c|c|c|c|c|c|c|c|}
\hline & $\begin{array}{c}\text { Controls } \\
n=567(\%)\end{array}$ & $\begin{array}{c}A^{\mathrm{a}} \\
\mathrm{n}=472(\%)\end{array}$ & $\mathrm{OR}^{\mathrm{b}}$ & $95 \% \mathrm{Cl}^{\mathrm{c}}$ & $\begin{array}{c}\text { ALL }^{\mathrm{d}} \\
\mathrm{n}=407(\%)\end{array}$ & $\mathrm{OR}^{\mathrm{b}}$ & $95 \% \mathrm{Cl}^{\mathrm{c}}$ & $\begin{array}{c}\text { AML }^{\mathrm{e}} \\
\mathrm{n}=62(\%)\end{array}$ & $\mathrm{OR}^{\mathrm{b}}$ & $95 \% \mathrm{Cl}^{\mathrm{c}}$ \\
\hline \multicolumn{11}{|l|}{ DURING PREGNANCY } \\
\hline No & $203(37)$ & $154(34)$ & 1.0 & reference & $134(34)$ & 1.0 & reference & $20(33)$ & 1.0 & reference \\
\hline Yes & 341 (63) & $298(66)$ & 1.1 & {$[0$.} & $255(66)$ & 1.1 & & $40(67)$ & 1.6 & \\
\hline$\leq 3$ & $296(55)$ & $245(54)$ & 1.1 & {$[0.8$} & $208(54)$ & 1.1 & 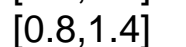 & $35(59)$ & 1.6 & $3.0]$ \\
\hline$>3$ cups / day & $45 \quad(8)$ & $53(12)$ & 1.5 & {$[0.9,2.4]$} & $47(12)$ & 1.4 & {$[0.9,2.4]$} & $5 \quad(8)$ & 1.4 & {$[0.5,4.4]$} \\
\hline \multicolumn{11}{|l|}{ AT TIME OF INTERVIEW } \\
\hline No & $108(19)$ & $81(18)$ & 1.0 & refe & $71(18$ & 1. & ref & $10(16)$ & 1.0 & reference \\
\hline Yes & 451 (81) & 381 (82) & 1.1 & {$[0.8,1.5]$} & 327 (82) & 1.0 & {$[0.7,1.5]$} & 51 (84) & 1.4 & {$[0.6,3.0]$} \\
\hline$\leq 3$ cups $/ \mathrm{da}$ & $364(65)$ & $295(64)$ & 1.1 & {$[0.8,1.5]$} & $254(64)$ & 1.0 & {$[0.7,1.4]$} & 39 (64) & 1.3 & {$[0.6,2.8]$} \\
\hline$>3$ cups / day & 87 (16) & 86 (19) & 1.2 & {$[0.8,1.9]$} & 47 (18) & 1.2 & {$[0.7,1.8]$} & $12(20)$ & 1.8 & {$[0.7,4.7]$} \\
\hline
\end{tabular}

${ }^{\mathrm{a}} \mathrm{AL}$ : Acute Leukemia ${ }^{\mathrm{b}}$ Odds ratios adjusted for age, gender, region, socio-professional category and birth order ${ }^{\mathrm{c}} 95 \% \mathrm{Cl}: 95 \%$ Confidence Interval ${ }^{\mathrm{d}}$ ALL: Acute Lymphoblastic Leukemia ${ }^{\mathrm{e}}$ AML: Acute Myeloblastic Leukemia 
Table 4: Parental smoking and childhood leukemia

\begin{tabular}{|c|c|c|c|c|c|c|c|c|}
\hline $\begin{array}{l}\text { Controls } \\
=567(\%)\end{array}$ & $\begin{array}{c}\mathbf{A L}^{\mathrm{a}} \\
\mathrm{n}=472(\%\end{array}$ & OR & $95 \% \mathrm{Cl}^{\mathrm{C}}$ & $\begin{array}{c}\text { ALL }^{\mathrm{d}} \\
\mathrm{n}=407(\%)\end{array}$ & $\mathrm{OR}^{\mathrm{b}}$ & $95 \% \mathrm{Cl}^{\mathrm{C}}$ & $\begin{array}{c}\text { AML }^{\mathrm{e}} \\
\mathrm{n}=62(\%)\end{array}$ & $\mathrm{OR}^{\mathrm{b}} \quad 95 \% \mathrm{Cl}^{\mathrm{C}}$ \\
\hline
\end{tabular}

\section{MATERNAL SMOKING}

Before pregnancy ${ }^{\ddagger}$

$$
\begin{aligned}
& \text { No } \\
& \leq 10 \text { cig. / day } \\
& >10 \text { cig. / day }
\end{aligned}
$$

$\begin{array}{rlrlll}357 & (66) & 302 & (67) & \mathbf{1 . 0} & \text { reference } \\ 105 & (19) & 81 & (18) & \mathbf{0 . 9} & {[0.6,1.3]} \\ 79(15) & 69 & (15) & \mathbf{1 . 0} & {[0.7,1.4]}\end{array}$

$\begin{array}{rlll}256 & (66) & 1.0 & \text { reference } \\ 72 & (18) & 1.0 & {[0.7,1.4]}\end{array}$

$63(16) \quad 1.1 \quad[0.7,1.6]$

$43(74)$

$9(16)$

6 (10)

1.0 reference

$\mathbf{0 . 6}[0.3,1.3]$

During pregnancy

No
Yes

$\begin{array}{rrrlll}463 & (83) & 372 & (79) & 1.0 & \text { reference } \\ 97 & (17) & 98 & (21) & 1.3 & {[0.9,1.7]} \\ 58 & (10) & 50 & (11) & 1.1 & {[0.7,1.7]} \\ 37 & (7) & 44 & (10) & 1.4 & {[0.9,2.2]}\end{array}$

315 (78) 1.0 reference

54 (87)

$0.6[0.2,1.4]$

$$
\leq 5 \text { cig. / day }
$$

$>5$ cig. / day

$37 \quad(7)$

44 (10) $1.4 \quad[0.9,2.2]$

$90 \quad(22) \quad 1.4 \quad[1.0,1.9]$

8 (13)

1.0 reference

48 (12) $\quad 1.3 \quad[0.9,2.0]$

41 (10) $1.5 \quad[0.9,2.5]$

2 (3)

$0.6[0.3,1.5]$

During childhood§

$$
\begin{aligned}
& \text { No } \\
& \leq 10 \text { cig. / day } \\
& >10 \text { cig. / day }
\end{aligned}
$$

$$
\begin{array}{rlrlll}
377 & (69) & 315 & (70) & \mathbf{1 . 0} & \text { reference } \\
97 & (18) & 74 & (16) & \mathbf{0 . 9} & {[0.6,1.3]}
\end{array}
$$

267 (68) $\quad 1.0$ reference

$67(17)$

$\begin{array}{ll}1.0 & \text { reference } \\ \mathbf{1 . 0} & {[0.7,1.4]}\end{array}$

57 (15) $1.1 \quad[0.8,1.7]$

3 (5)

$0.2[0.04,1.0]$

68 (13)

63 (14)

$1.1[0.7,1.5]$

$\begin{array}{lllllll}278 & (53) & 207 & (50) & 1.0 & \text { reference } \\ 214 & (41) & 180 & (43) & 1.2 & {[0.9,1.6]}\end{array}$

176 (49) $\quad \mathbf{1 . 0}$ reference

156 (43) $1.2 \quad[0.9,1.6]$

$\begin{array}{llll}27 & (8) & 1.2 & {[0.7,2.0]}\end{array}$

$45(78)$

7 (12)

6 (10)

$0.7[0.2,2.6]$

Before pregnancy

$$
\leq 20 \text { cig. / day }
$$

$>20$ cig. / day

$33(6)$

28 (7) $1.0 \quad[0.6,1.7]$

238 (46) $173(42) \quad \mathbf{1 . 0}$ reference

146 (41) $\quad 1.0$ reference

176 (50) $1.2 \quad[0.9,1.6]$ $\begin{array}{llll}30 & (9) & 1.3 & {[0.8,2.3]}\end{array}$
29 (55) $\quad 1.0$ reference $23(43) \quad 0.9 \quad[0.5,1.7]$
$\begin{array}{llll}1 & (2) & 0.2 & {[0.02,1.7]}\end{array}$

During childhood§

No
$\leq 2$ cig. / day

$>20$ cig. / day

244 (47) 204 (50) $1.2 \quad[0.9,1.5]$

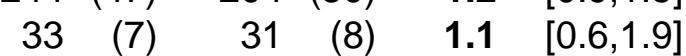

30

$\begin{array}{rrrl}25 & (47) & \mathbf{1 . 0} & \text { reference } \\ 27 & (51) & \mathbf{1 . 1} & {[0.5,1.8]} \\ 1 & (2) & \mathbf{0 . 2} & {[0.03,1.7]}\end{array}$

${ }^{\mathrm{a}} \mathrm{AL}$ : Acute Leukemia ${ }^{\mathrm{b}}$ Odds ratios adjusted for age, gender, region, socio-professional category and birth $\operatorname{order}^{\mathrm{c}} 95 \% \mathrm{Cl}$ : $95 \% \mathrm{Confidence}$ Interval ${ }^{\mathrm{d}}$ ALL: Acute Lymphoblastic Leukemia ${ }^{\mathrm{e}}$ AML: Acute Myeloblastic Leukemia 
Table 5: Maternal smoking, coffee and alcohol during pregnancy in childhood acute leukemia (multivariate model)

\begin{tabular}{|c|c|c|c|c|c|c|}
\hline & & \multicolumn{2}{|r|}{$A L L^{b}$} & \multicolumn{2}{|r|}{$A M L^{c}$} \\
\hline & $O^{d}$ & $95 \% \mathrm{Cl}^{\mathrm{e}}$ & $O^{d}$ & $95 \% \mathrm{Cl}^{\mathrm{e}}$ & $O R^{d}$ & $95 \% \mathrm{Cl}^{\mathrm{e}}$ \\
\hline Maternal smoking during pregnancy (Yes vs. no) & 1.2 & {$[0.8,1.6]$} & 1.3 & {$[0.9,1.9]$} & 0.3 & {$[0.1,1.0]$} \\
\hline$\leq 5$ cig. / day & 1.0 & {$[0.7,1.6]$} & 1.3 & {$[0.8,2.0]$} & 0.2 & {$[0.1,1.0]$} \\
\hline$>5$ cig. / day & 1.3 & {$[0.8,2.1]$} & 1.4 & {$[0.8,2.3]$} & 0.6 & {$[0.2,2.5]$} \\
\hline Maternal coffee during pregnancy (Yes vs. no) & 1.1 & {$[0.8,1.4]$} & 1.0 & {$[0.7,1.4]$} & 1.7 & {$[0.9,3.4]$} \\
\hline$\leq 3$ cups / day & 1.0 & {$[0.8,1.4]$} & 1.0 & {$[0.7,1.3]$} & 1.7 & {$[0.8,3.2]$} \\
\hline$>3$ cups / day & 1.5 & {$[0.9,2.4]$} & 1.4 & {$[0.8,2.3]$} & 2.6 & {$[0.8,8.6]$} \\
\hline Maternal alcohol during pregnancy (Yes vs. no) & 1.1 & {$[0.7,1.7]$} & 1.2 & {$[0.8,1.9]$} & 0.2 & {$[0.1,1.1]$} \\
\hline$\leq 1$ glass / day & 0.8 & {$[0.4,1.3]$} & 0.8 & {$[0.5,1.5]$} & - & \\
\hline$>1$ glass / day & 2.3 & {$[1.1,4.9]$} & 2.7 & {$[1.2,5.7]$} & - & \\
\hline
\end{tabular}

for age, gender, region, socio-professional category and birth order ${ }^{\mathrm{e}} 95 \% \mathrm{Cl}$ : $95 \%$ Confidence Interval 